\title{
Preparation and Quality Assessment of Yoghurt Prepared from Dairy Milk and Coconut (Cocos nucifera, $L$ ) Milk
}

\author{
S.R Priya ${ }^{1}$ and Dr. Lalitha Ramaswamy ${ }^{2}$
}

\begin{abstract}
Yoghurt was produced using dairy and coconut milk. Five variants of yoghurt namely plain dairy and coconut yoghurt (variant I), dairy and coconut yoghurt with natural grape pulp (variant II), dairy and coconut yoghurt with synthetic grape flavour (variant III), dairy and coconut yoghurt with natural pineapple pulp (variant IV) and dairy and coconut yoghurt with synthetic pineapple flavour (variant V) were prepared. Among these five variants dairy and coconut yoghurt with pineapple pulp (variant IV) had received the highest mean scores for all the sensory criteria, and was selected for the further study. Physicochemical properties and selected nutrient components were analysed for the pineapple flavoured yoghurt prepared with dairy milk and coconut milk. Yoghurt made with coconut milk had scored higher values for all the analysed nutrients (energy - $142.49 \pm 2.63$, carbohydrate $-9.55 \pm 0.12$, protein $-8.02 \pm 0.005$ and fat $-13.03 \pm 0.05$ ) than yoghurt made with dairy milk (energy $-93.76 \pm 0.25$, carbohydrate $-4.46 \pm 0.05$, protein $-7.26 \pm 0.11$ and fat $-9.82 \pm 0.02$ ). The results of current study demonstrated that the addition of fruits to the yogurt significantly improved the product acceptability and also yoghurt produced from coconut milk can be a match able substitute for normal yoghurt.
\end{abstract}

Keywords: Coconut Yoghurt; Dairy Yoghurt; Lactose intolerance; Nutrient analysis; Sensory evaluation

\section{Introduction}

Yoghurt is a fermented product obtained through an anaerobic fermentation of lactose in milk by relevant microorganisms most of which are classified as pro-biotic (Tull, 1996). The substrate that is usually employed in this type of yoghurt is evaporated whole milk/skimmed solids or fresh milk from cow. Although this substrate produces good quality yoghurt, there are certain limitations for vegans and lactose intolerance people to consume. Even though the lactose gets converted into lactic acid by the bacteria during fermentation some people show allergic reactions by consumption. It is realized that strict vegetarians are also limited in their quest for probiotic yoghurts when there is the confinement to only animal base yoghurt. Selection of possible substrates which have the potential to produce yoghurt with comparable effect as seen with cow milk is necessary. It is therefore of great importance to find out the feasibility of using the coconut milk as substrate for yoghurt production as used in other experimental substrates such as, soy bean milk and tiger nuts milk (Belewu and Belewu, 2007), Soy coconut milk (Kolapo and Olubamiwa, 2012) and Sesame milk (Afaneh et al., 2011).

\footnotetext{
${ }^{1}$ Ph.D Scholar, ${ }^{2}$ Associate Professor and HOD, Department of Nutrition and Dietetics, PSG College of Arts and Science, Coimbatore - 641 014, India.

E-mail: priyaramsay84@gmail.com
}

Phone No: 9842582051 
Belewu et al. (2005) have also documented the combination of soymilk $(50 \%)$ and coconut milk $(50 \%)$ in the preparation of soy-coconut yoghurt. Yoghurt obtained by using coconut milk has been found to be delicious and a nutritional product (Imele and Atemnkeng, 2001).

Coconut (Cocos nucifera) milk is being used by confectionaries, bakeries, biscuits and ice cream industries worldwide to enhance flavor and taste of various products (Persley, 1992). Current trends and changing consumer needs indicate a great opportunity for innovations and developments in fermented milks. Non-dairy products have shown a great sensory appeal (Soler, 2005; Potter et al., 2007; Granato et al., 2010 and Branco et al., 2010) and market potential worldwide due to a high percentage of population that present lactose-intolerance. Coconut milk was found to be rich in calcium. The milk was reported to be high in minerals and vitamin content (Nieuwentus and Nieuwelink, 2002) while total saturated fat was $10 \%$ of the total energy (Thai Food Composition, 2004). In the light of the above, this research was taken to promote the use of coconut in the production of yoghurt, and also to evaluate the range of acceptability of the flavoured yoghurt through sensory evaluation.

\section{Materials and methods}

\section{Material collection}

The ingredients required for the preparation of the yoghurt were dairy milk, coconut milk, tapioca starch, sugar, china grass and thermophilic bacterial culture. Farm fresh dairy milk was used for the study. Coconut milk was prepared from the matured coconut (9-10 months old) freshly picked from the coconut tree in the farm. The ingredients like tapioca starch, sugar and china grass were purchased from the local market. The thermophilic culture was purchased from Chr Hansen Food Product Company, Denmark.

\section{Extraction and preparation of coconut milk}

The coconut milk was extracted by the method followed by Akoma et al. (2000). The coconut was crushed open and coconut flesh was then grated from the shell and homogenized in a blender together with double the quantity of water. It was then passed through a fine sieve. The extracted coconut milk was transferred into a vessel and pasteurized at $90^{\circ} \mathrm{C}$ with the addition of $1 \%$ sugar, $2 \%$ tapioca starch and 0.3 $\%$ of china grass and allowed to cool gradually to a temperature of $42-45^{\circ} \mathrm{C}$ and the mixture is blended in the mixer for the fine consistency of the yoghurt and was inoculated with thermophilic bacteria.

\section{Preparation of dairy milk}

The dairy milk was pasteurized at $90^{\circ} \mathrm{C}$ and allowed to cool gradually to a temperature of $42-45^{\circ} \mathrm{C}$ for the addition of thermophilic bacterial culture. Pasteurization is believed to modify milk protein so as to enhance proper viscosity and gelatinization of the product (Reed, 1982).

\section{Preparation of culture}

The thermophilic bacterial culture containing of Lactobacillus bulgaricus, Lactobacillus lactis and Streptococcus thermophiles was purchased from Chr Hansen company. It was available in $25 \mathrm{~g}$ packets. One packet is used to culture 250 liters of milk for the preparation of the yoghurt in the aavin milk company, runs under the state government of Tamilnadu. The same procedure was adopted for the research work, the content is mixed in 250 $\mathrm{ml}$ of the water at $12^{\circ} \mathrm{C}$ inside the laminar flow. After setting, the culture was stored at freezing temperature for the further use. From this bulk culture $1 \mathrm{ml}$ is used to prepare one liter of the yoghurt.

\section{Fruit preparation}

Pineapple and grapes were used for the yoghurt variants. The pineapple was washed and its pulp obtained from the crushed fruit. Grape fruit was washed and chopped. 10\% ratio sugar was mixed with grape and pineapple and pasteurized separately at $80^{\circ} \mathrm{C}$ for 20 minutes, and filled into separate jars. These pulps were stored at ambient temperature until added to yogurt. 
Table 1. Quantification of Ingredients for 100g of the Yoghurt Variants

\begin{tabular}{|l|c|c|c|c|c|c|c|c|c|c|}
\hline Ingredients & \multicolumn{2}{|c|}{$\begin{array}{c}\text { Variant I } \\
\text { (Plain) }\end{array}$} & \multicolumn{2}{c|}{$\begin{array}{c}\text { Variant II } \\
\text { (Natural } \\
\text { Grape) }\end{array}$} & \multicolumn{2}{c|}{$\begin{array}{c}\text { Variant III } \\
\text { (Synthetic } \\
\text { grape ) }\end{array}$} & \multicolumn{2}{c|}{$\begin{array}{c}\text { Variant IV } \\
\text { (Natural } \\
\text { pineapple) }\end{array}$} & \multicolumn{2}{c|}{$\begin{array}{c}\text { Variant V } \\
\text { (Synthetic } \\
\text { pineapple) }\end{array}$} \\
\cline { 2 - 13 } & $\mathbf{A}$ & $\mathbf{B}$ & $\mathbf{A}$ & $\mathbf{B}$ & $\mathbf{A}$ & $\mathbf{B}$ & $\mathbf{A}$ & $\mathbf{B}$ & $\mathbf{A}$ & B \\
\hline Dairy milk & $100 \mathrm{ml}$ & - & $100 \mathrm{ml}$ & - & $100 \mathrm{ml}$ & - & $100 \mathrm{ml}$ & - & $100 \mathrm{ml}$ & - \\
\hline Coconut milk & - & $100 \mathrm{ml}$ & - & $100 \mathrm{ml}$ & - & $100 \mathrm{ml}$ & - & $100 \mathrm{ml}$ & - & $100 \mathrm{ml}$ \\
\hline Tapioca starch & - & $2 \mathrm{~g}$ & - & $2 \mathrm{~g}$ & - & $2 \mathrm{~g}$ & - & $2 \mathrm{~g}$ & - & $2 \mathrm{~g}$ \\
\hline Agar agar & - & $0.3 \mathrm{~g}$ & - & $0.3 \mathrm{~g}$ & - & $0.3 \mathrm{~g}$ & - & $0.3 \mathrm{~g}$ & - & $0.3 \mathrm{~g}$ \\
\hline Sugar & - & $1 \mathrm{~g}$ & - & $1 \mathrm{~g}$ & - & $1 \mathrm{~g}$ & - & $1 \mathrm{~g}$ & - & $1 \mathrm{~g}$ \\
\hline $\begin{array}{l}\text { Thermophilic } \\
\text { Culture }\end{array}$ & $0.1 \mathrm{ml}$ & $0.1 \mathrm{ml}$ & $0.1 \mathrm{ml}$ & $0.1 \mathrm{ml}$ & $0.1 \mathrm{ml}$ & $0.1 \mathrm{ml}$ & $0.1 \mathrm{ml}$ & $0.1 \mathrm{ml}$ & $0.1 \mathrm{ml}$ & $0.1 \mathrm{ml}$ \\
\hline Natural grape & - & - & $15 \mathrm{~g}$ & $15 \mathrm{~g}$ & - & - & - & - & - & - \\
\hline $\begin{array}{l}\text { Synthetic } \\
\text { grape }\end{array}$ & - & - & - & - & $0.5 \mathrm{ml}$ & $0.5 \mathrm{ml}$ & - & - & - & - \\
\hline $\begin{array}{l}\text { Natural } \\
\text { pineapple }\end{array}$ & - & - & - & - & - & - & $15 \mathrm{~g}$ & $15 \mathrm{~g}$ & - & - \\
\hline $\begin{array}{l}\text { Synthetic } \\
\text { pineapple }\end{array}$ & - & - & - & - & - & - & - & - & $0.5 \mathrm{ml}$ & $0.5 \mathrm{ml}$ \\
\hline
\end{tabular}

A- DAIRY YOGHURT

\section{Preparation of yoghurt}

Five different variants in both dairy and coconut yoghurt were prepared. Several practical attempts were carried out with different levels of ingredients so as to select the range of percent incorporation which could be used in formulating the different variants of yoghurts. In order to make yoghurt processing attractive quite a number of process manipulations have been adopted including evaporation or concentration, addition of solids in the form of different starch, addition of different fruit pulp and synthetic fruit flavours and the lavels of starter cultures to make the yoghurt thick and free from whey separation. Through trial and error and by informal sensory evaluation the levels of ingredients were fixed (Table 1).
Pasteurized and cooled substrates were inoculated with the prepared culture $(1 \mathrm{ml}$ was used to inoculate 1 litre). The mixture was then filled in yoghurt maker bottles and kept in the yoghurt maker for 6-7 hours to allow for fermentation. The yoghurt maker maintains the temperature between $42-45^{\circ} \mathrm{C}$. When the $\mathrm{pH}$ lies between $4.5-4.8$, yoghurts were removed from the yoghurt maker and added with synthetic flavours and natural fruit pulp and stored at refrigerated temperature.

\section{Sensory evaluation of the different variants of yoghurt}

Sensory Evaluation is defined as "A scientific discipline used to evoke, measure, analyze, and interpret those responses to products that are perceived by the senses of sight, smell, touch, taste, and hearing (Stone and 
Sidel, 1993)." The product acceptability was assessed using a 9 point hedonic scale for the quality factors such as colour, flavor, taste, consistency and overall acceptability by a panel consisting of ten judges. The judges included the professors, research scholars and junior research fellows of the department of Food and Nutrition. The scoring scale was: 1 (Dislike extremely), 2 (Dislike very much), 3 (Dislike moderately), 4 (Dislike slightly), 5 (Neither dislike nor acceptable), 6 (Slightly acceptable), 7 (Moderately acceptable), 8 (Highly acceptable) and 9 (Extremely acceptable) (Amerine et al., 1965).

\section{Analysis of physico chemical properties and selected nutrient components for the milk samples and yoghurts}

Milk samples and the selected yoghurt variant from the sensory evaluation were analysed in triplicates for physico chemical properties. $\mathrm{Ph}$ was determined in a digital type $\mathrm{pH}$ meter. Total acidity, total solids and moisture were determined using AOAC (1990). The method of Isanga and Zhang (2009) was used to determine susceptibility to synergies (STS). The yoghurt sample $(20 \mathrm{ml})$ was placed on a filter paper on top of a funnel and allowed to drain for $3 \mathrm{~h}$. The index of synergisis was calculated from the formula:

$$
\text { STS }(\%)=V 1 / \mathrm{V} 2 \times 100 .
$$

$[\mathrm{V} 1=$ Volume of whey collected after drainage; V2 = Volume of yoghurt sample].

The method of Harte et al. (2003), with slight modification, was used to determine the water holding capacity (WHC) of stirred yoghurt samples after subjecting them to $15 \mathrm{~min}$ centrifugation at $6000 \mathrm{rpm}$ at $5^{\circ} \mathrm{C}$ in a centrifuge.

WHC was calculated using the formula: $\operatorname{WHC}(\%)=\{1-[\mathrm{W} 1 / \mathrm{W} 2]\} \times 100$

[W1 $=$ weight of whey after centrifugation and $\mathrm{W} 2$ = weight of the yoghurt used].

Milk samples and the selected yoghurt variant form the sensory evaluation were analyzed in triplicates for the nutrient components namely energy, carbohydrate, protein, and fat by AOAC method (1990).

\section{Results and discussion}

\section{Sensory evaluation}

Using the rating test, differences were observed for degree of liking of colour, flavor, taste, consistency and overall acceptability. Dairy yoghurt with natural grape had got least score for colour $(6.9 \pm 1.52)$ (Table 2), pineapple flavoured coconut yoghurt had scored high for all the sensory criteria (colour $(8.7 \pm 0.95)$, taste $(8.6 \pm 0.52)$, consistency $(8.3 \pm 0.48)$ and overall acceptability $(8.4 \pm 0.52)$ except flavour. In food products, especially fruit-based ones, the consumer often assesses the initial quality by their color and appearance; hence these attributes are the primary indicators of perceived quality (Lawless and Heymann, 1999). Moreover, color is a parameter for consideration for novel foods due to their initial acceptability by potential consumers, and color also determines purchase and regular consumption of products (Tarrega and Costell, 2007). The combination of pineapple and coconut yoghurt was excellent. Plain dairy yoghurt scored highest value for the flavor $(8.6 \pm 0.70)$ on comparison with other variants, this might be because all the panelists were used to dairy yoghurt for a long period which might have influence the degree of liking for flavor than others.

Coconut yoghurt had scored high mean score for consistency in all the variants on comparison with dairy yoghurt, this is particularly due to the inclusion of stabilizer $(0.3$ percent) in coconut yoghurt. Chawla and Balachandran (1994) stated that incorporation of SNF in milk contribute to refinement in taste of yoghurt with improved consistency, viscosity and reduced whey separation. Stabilizer levels had significant effect on body and texture of indicating that the frozen yoghurt at 0.5 percent stabilizer was the best quality product with firm body and smooth texture.

Among all the five variants, variant IV (Natural pineapple) had received highest scores for the sensory attributes (pineapple flavoured dairy milk yoghurt colour $-8.4 \pm 1.07$, flavor $8.5 \pm 0.97$, taste $-8.3 \pm 0.82$, consistency -7.3 \pm 1.70 , and overall acceptability $-8.3 \pm 1.34$ and coconut milk yoghurt colour $-8.7 \pm 0.95$, 
Table 2. Mean Organoleptic Scores of the Yoghurt Variants

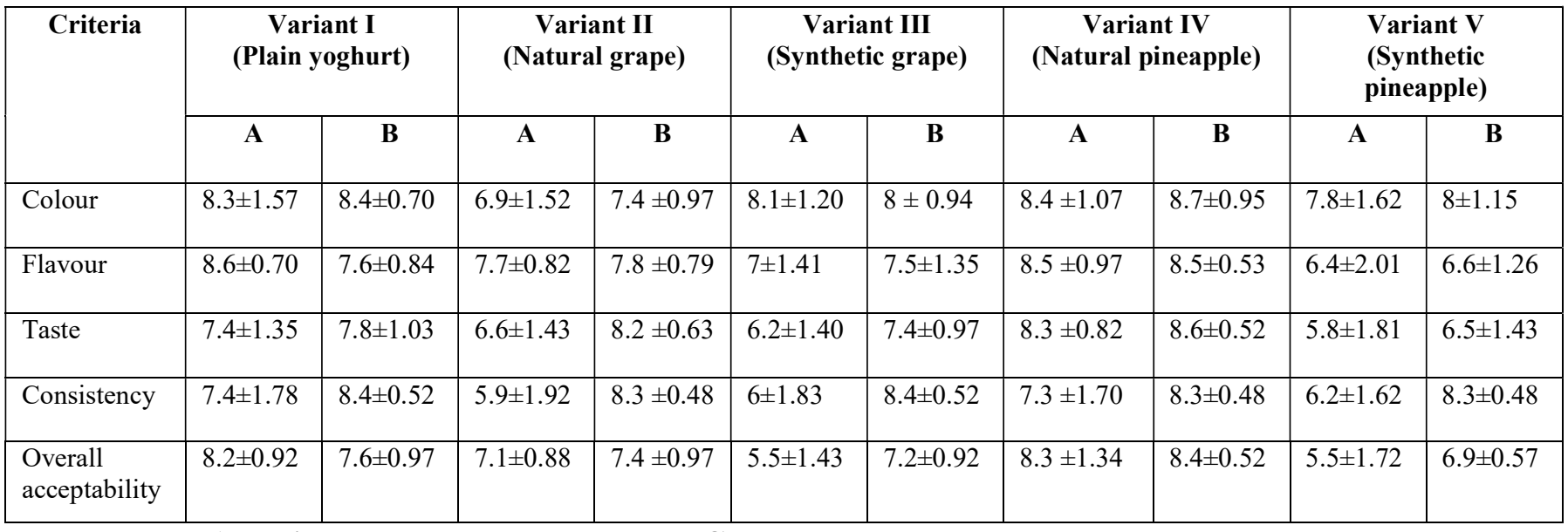

A- Dairy yoghurt

B- Coconut yoghurt

Table 3. Physicochemical properties of the milk samples

\begin{tabular}{|l|l|c|c|}
\hline S. no & Parameters & Dairy milk & Coconut milk \\
\hline 1 & PH & $6.26 \pm 0.05$ & $5.28 \pm 0.02$ \\
\hline 2 & Total solids & $14.30 \pm 0.01$ & $19.70 \pm 0.005$ \\
\hline 3 & Total acidity & $0.77 \pm 0.005$ & $0.91 \pm 0$ \\
\hline 4 & Moisture & $85.67 \pm 0.01$ & $81.23 \pm 0.05$ \\
\hline
\end{tabular}

flavor $-8.5 \pm 0.53$, taste $-8.6 \pm 0.52$, consistency $-8.3 \pm 0.48$, and overall acceptability $-8.4 \pm 0.52$ ). Hence, it was selected for the further study. The flavors are key factors for food stuff acceptability by consumers. Organoleptic evaluations have shown a marked preference for the fruity yoghurt (Barnes et al., 1991). Addition of different fruit in yogurt manufacture has been attempted increasingly. Fruit yogurt has more taste and pleasing flavor (Mahmood et al., 2008).

Physicochemical properties of the milk samples and pineapple flavoured yoghurt

The $\mathrm{pH}$ values of the dairy milk (6.26 \pm $0.05)$ (Table 3 ) and coconut milk (5.28 \pm 0.02$)$ were similar (dairy milk - 6.3 and coconut milk -6.0) to the results by Ladokun and Oni (2014). The total solid of dairy milk was $14.30 \pm 0.0$, which is lower than coconut milk (19.70 \pm $0.005)$.
The total acidity of dairy and coconut milk were $0.77 \pm 0.005$ and $0.91 \pm 0$ respectively. The significance of moisture content in milk is that, high moisture content implies high water activity which supports microbial growth consequently reducing the shelf life of the milk sample (Ajai et al., 2012). The moisture level of the dairy milk $(85.67 \pm 0.01)$ is higher than the coconut milk $(81.23 \pm 0.05)$.

The $\mathrm{pH}$ of the yoghurt prepared from dairy milk and coconut milk was $4.6 \pm 0$ and $4.76 \pm$ 0.05 respectively (Fig. 1). The yoghurt is removed from the yoghurt maker to stop fermentation once the $\mathrm{pH}$ reaches between 4.5 4.8. To reach this particular range of $\mathrm{pH}$, the yoghurts was kept in the yoghurt maker for about $6-7$ hours.

The total solids of the yoghurt (dairy $19.57 \pm 0.50$, coconut - 26.51 \pm 0.01 ) were increased after fermentation on comparison with 
the total solids of the initial levels of the milk (dairy - $14.30 \pm 0.01 \%$, coconut $-19.70 \pm 0.005$ $\%$ ). The total solids are an indication of the dry matter content of the yoghurt samples (Belewu et al., 2010 and Khalifa et al., 2011).

Yoghurt made with dairy milk and coconut milk has the total acidity of $0.94 \pm 0 \%$ and $0.87 \pm 0.005 \%$ respectively. Estevez et al. (2010) also reported that higher total solids led to more acid production than lower total solids in soy yoghurts. Yousef et al. (2013) had recorded the acidity of fruit yoghurts from 0.83- 1.21 percent.

The water holding capacity of the yoghurt made with dairy milk was $57 \pm 0$ and coconut milk was $77.67 \pm 0.57$. Lower WHC or whey separation is referring to a weakness of gel network (Singh and Muthukun, 2008). Kovalenko and Briggs (2002) showed 84.1-96 \% of WHC in soy-based desserts. The STS in dairy yoghurt $(41.33 \pm 1.15 \%)$ was high on comparision with $(11.67 \pm 0.57 \%)$ coconut yoghurt. Granato et al. (2010) developed soybased desserts with the addition of oligo fructose and different concentrations of guava juice (22, 27 , and $32 \%$ ) and soy protein $(1,2$, and $3 \%)$ and found that only the sample containing $27 \%$ of guava juice and $1 \%$ of soy protein had whey formation after centrifugation $(7.0 \%)$, while all other desserts presented $100 \%$ WHC after 72 hours of refrigeration.

Ranganadhan and Gupta (1987) state that good quality yoghurt was a gel like coagulation and porcelain like surface without wheying off, this statement was in agreement with the coconut yoghurt in the present investigation. The improvement in WHC and STS in the coconut yoghurt is may be due to the addition of stabilizer (0.3 percent china grass) and thickening agent ( 2 percent tapioca starch).

The moisture content of different types of yogurt varied from 71.7- 86.3 percent (Yousef et al., 2013), which was in close relation in the present research, the moisture content of the yoghurt made with dairy milk was $80.11 \pm 0.01$ and the coconut milk was $73.45 \pm 0.01$. Moisture content and the total solids affected the texture, low moisture content and high total solid increased the firmness and consistency of yogurt and therefore gives acceptable mouthfeel.

\section{Analysis of selected nutrient components of milk samples and pineapple flavoured yoghurt}

The energy, protein, and fat levels of coconut milk $(199.29 \pm 0.25,10.37 \pm 0.22,17.07$ $\pm 0.01)$, is higher than dairy milk $(64.24 \pm 0.04$, $9.3 \pm 0,8.8 \pm 0)$. The carbohydrate level of coconut milk is less $(1.30 \pm 0.01)$ than dairy milk $(2.70 \pm 0.01)$ (Table 4).

The fat content of the milk samples ranged from $8.8 \pm 0-17.07 \pm 0.01 \%$. The major contrast in the food proximate content was the values obtained for the fat contents. From previous studies, fat contents are usually higher in animal origin than plant origin (Belewu et al. 2010). The findings in this study disagree with earlier studies because coconut milk has the fat content of $17.07 \pm 0.01 \%$, and dairy milk has 8.8 \pm 0 .

Yoghurt made from coconut milk had higher nutritional values than dairy milk. The energy value of yoghurt made from dairy milk was $93.76 \pm 0.25$ and that of coconut milk was $142.49 \pm 2.63$, which is nearly one and half times higher than dairy yoghurt. Tapioca starch was added in the preparation of coconut yoghurt, which was not used for dairy yoghurt because coconut yoghurt oozes much water during the fermentation process. To enhance the product appeal tapioca starch (2 percent) was added to the coconut yoghurt, which had an impact in raising the carbohydrate level than dairy yoghurt. The carbohydrate content was $4.46 \pm 0.05$ and $9.55 \pm 0.12$ for yoghurt made from dairy and coconut milk respectively. In the proximate analysis, the carbohydrate level of coconut milk $(1.30 \pm 0.01)$ is less than dairy milk $(2.70 \pm$ $0.01)$.

The energy, protein, and fat levels of coconut milk $(199.29 \pm 0.25,10.37 \pm 0.22,17.07$ $\pm 0.01)$, is higher than dairy milk (64.24 \pm 0.04 , $9.3 \pm 0,8.8 \pm 0)$. The carbohydrate level of coconut milk is less $(1.30 \pm 0.01)$ than dairy milk $(2.70 \pm 0.01)$. 
Figure 1. Physicochemical properties of the pineapple flavoured yoghurt

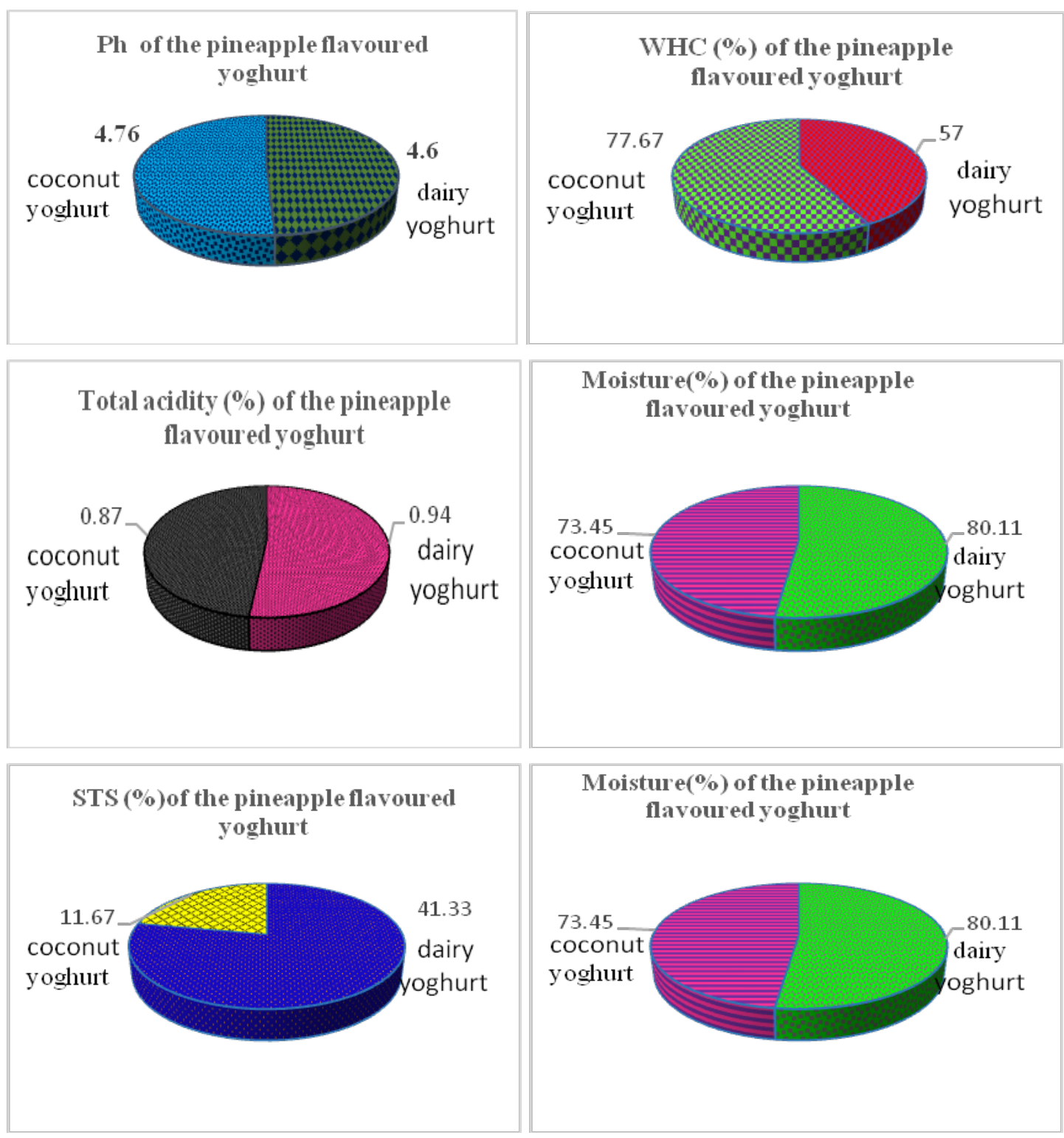

Table 4. The nutrient content of pineapple flavoured yoghurt and milk samples (100g)

\begin{tabular}{|c|l|c|c|c|c|}
\hline S. No & \multicolumn{1}{|c|}{ Nutrients } & $\begin{array}{c}\text { Dairy } \\
\text { yoghurt }\end{array}$ & $\begin{array}{c}\text { Coconut } \\
\text { yoghurt }\end{array}$ & $\begin{array}{c}\text { Dairy } \\
\text { milk }\end{array}$ & $\begin{array}{c}\text { Coconut } \\
\text { milk }\end{array}$ \\
\hline 1 & Energy (Kcal) & $93.76 \pm 0.25$ & $142.49 \pm 2.63$ & $64.24 \pm 0.04$ & $199.29 \pm 0.25$ \\
\hline 2 & Carbohydrate $(\mathrm{g})$ & $4.46 \pm 0.05$ & $9.55 \pm 0.12$ & $2.70 \pm 0.01$ & $1.30 \pm 0.01$ \\
\hline 3 & Protein (g) & $7.26 \pm 011$ & $8.02 \pm 0.005$ & $9.3 \pm 0$ & $10.37 \pm 0.22$ \\
\hline 4 & Fat (g) & $9.82 \pm 0.02$ & $13.03 \pm 0.05$ & $8.8 \pm 0$ & $17.07 \pm 0.01$ \\
\hline
\end{tabular}


The fat content of the milk samples ranged from $8.8 \pm 0-17.07 \pm 0.01 \%$. The major contrast in the food proximate content was the values obtained for the fat contents. From previous studies, fat contents are usually higher in animal origin than plant origin (Belewu et al., 2010). The findings in this study disagree with earlier studies because coconut milk has the fat content of $17.07 \pm 0.01 \%$, and dairy milk has 8.8 \pm 0 .

All the nutrients were higher in the yoghurt made from coconut milk than dairy milk. The energy value of yoghurt made from dairy milk was $93.76 \pm 0.25$ and that of coconut milk was $142.49 \pm 2.63$, which is nearly one and half times higher than dairy yoghurt. The carbohydrate content was $4.46 \pm 0.05$ and $9.55 \pm$ 0.12 for yoghurt made from dairy and coconut milk respectively. In the proximate analysis, the carbohydrate level of coconut milk $(1.30 \pm 0.01)$ is less than dairy milk $(2.70 \pm 0.01)$.

Tapioca starch was added in the preparation of coconut yoghurt, which was not used for dairy yoghurt because naturally dairy milk get curdled due to denaturation of protein during the fermentation process. In the coconut milk even though it has high protein content than dairy milk, the quality of the protein is not much related to dairy milk, thus oozes much water during the fermentation process. To enhance the product appeal tapioca starch (2 percent) was added to the coconut yoghurt, which had an impact in raising the carbohydrate level than dairy yoghurt.

The protein level of the yoghurt made from dairy milk $(7.26 \pm 011)$ and coconut milk $(8.02 \pm 0.005)$ were in the equal range. Ndife, et al. (2014) had reported the protein content of yoghurt enriched with coconut ranges between 2.17 to $3.05 \%$. The fat level of dairy yoghurt $(9.82 \pm 0.02)$ was less on comparison with coconut yoghurt $(13.03 \pm 0.05)$.

\section{Conclusion}

The data emanating from the present study depicts that, yoghurt can be prepared from coconut milk exclusively with stabilizer and thickening agent and can be comparable with normal dairy yoghurt. The sensory scores evoked that yoghurt is highly acceptable with natural pineapple pulp than synthetic. Coconut yoghurt also had good nutritional value on comparison with dairy yoghurt. The addition of fruit in the yoghurt could improve the taste preference of the yoghurt that one can expect. Coconut yoghurt could be helpful in meeting a significant portion of the daily needs of the nutrients for lactose intolerants, hence it can be recommended as a promising substitute for normal yoghurt.

\section{Acknowledgement}

The author is grateful to acknowledge the general manager aavin milk, Coimbatore for the help rendered in obtaining thermophilic bacterial culture from Chr Hansen food product company, Denmark.

\section{References}

A.O.A.C. (1990) Official Methods of Analysis. Association of official Analytical Chemists, $15^{\text {th }}$ Edition.

Adelodun, L., Kolapo, Abiodun, O., Olubamiwa. 2012. Effect of Different Concentrations of Coconut Milk on the Chemical and Sensory Properties of Soy-coconut Milk Based Yoghurt. Food and Public Health, 2(4): 85-91.

Akoma, O., Elekwa, U.O., Afodunrinbi, A.T., Onyeukwu, G.C. 2000. Yoghurt from Coconut and Tigernuts. J. Food Technol. Afr, 5 (4): 132-134.

Akpan, U.G., Mohammed, A.D., Aminu, I. 2007. Effect of Preservative on the Shelf Life of Yoghurt Produced from Soya Beans Milk. J. Pract. Technol 11: 131-142.

Amerine, M.A., Pangborn, R.M., Roessler, E.B. 1965. Principles of sensory evaluation of foods, Academic Press. New York.

Barnes, D.L., Harper, S.J., Bodyfelt, F.W., McDaniel, M.R. 1991. J Dairy Sci 74, 7, 2089-2099

Belewu, M.A., Bdelewu, K.Y., Olatunji, S.A. 2005. Soy-coconut Yoghurt: Preparation, Composition and Organoleptic Properties. Bio. Sci. Res. Bull. 21: 129-37. 
Belewu, M.A., Belewu, K.Y. 2007. Comparative Physico- Evaluation of Tiger-nut, Soybean and Coconut Milk Sources. Int. J. Agric. Biol 9: 785-787

Belewu, M.A., Belewu, K.Y., Bamidele, R.A. 2010. Cyper-coconut yoghurt: preparation, compositional and organoleptic qualities. African Journal of Food Science and Technology, Vol. 1(1): 010-012.

Branco, G.F. et al. 2010. Functional foods and non-dairy probiotic product food development: trends, concepts ad products. Comprehensive Reviews in Food Science and Food Safety, Vol. No. 9, 292-302,

Chawla, A.K., Balachandran, R. 1994. Indian J. DairySci 47(9): 762

Estevez A., Mejía, J., Figuerola, F., Escobar, B. 2010. Effect of solid content and sugar combinations on the quality of soymilkbased yogurt. Journal of Food Processing and Preservation, 34: 87-97.

Granato, D. et al. 2010. Physical stability assessment and sensory optimization of a dairy-free emulsion using response surface methodology. Journal of Food Science. 73, 149-155.

Harte, F., Luedecke, L., Swanson, B., BarbosaCanovas, G.V. 2003. Low- fat set yoghurt made from milk subjected to combinations of high hydrostatic pressure and thermal processing. J. Dairy Sci. 86:1074- 1082.

Ibrahim Afaneh, Khaled Abu-Alruz, Jihad M, Quasem, Ahmad Sundookah, Jehad Abbadi 2011. Fundamental Elements to Produce Sesame Yoghurt from Sesame Milk. American Journal of Applied Sciences 8 (11): 1086-1092, 2011 ISSN 1546-9239

Imele, H., Atemnkeng, A. 2001. Preliminary Study of the Utilisation of Coconut in Yoghurt Production. J. Food. Technol 6: 121-125.

Isanga, J., Zhang, G. 2009. Production and evaluation of some physicochemical parameters of peanut milk yoghurt. Food Sci. Technol 42:1132-1138.

Joel Ndife, Felicia Idoko, Rabiu Garba .2014. Production and quality assessment of functional yoghurt enriched with coconut. International Journal of Nutrition and Food Sciences 3(6): 545-550

Khalifa, M., Elgasim, A., Zaghloul, A., Maufouz, M. 2011. Application of inulin and mucilage as stabilizers in yoghurt production. American Journal of Food Technology. 1: 10- 17.

Kovalenko, I.V., Briggs, J.L. 2002. Textural characterization of soy- based yogurt by the vane method. Journal of Texture Studies 33 (2), 105-118.

Lawless, H.T., Heymann, H. 1999. Sensory evaluation of food: principles and practices. Aspen Publishers, 827.

Mahmood, N., Abbas, A.H., Gilani, A.H. 2008. Pakistan Journal of Agricultural Science. 45, (2) 275- 279.

Morvarid Yousef, Leila Nateghi, Elham Azadi. 2013. Effect of different concentration of fruit additives on some physicochemical properties of yoghurt during storage. Annals of Biological Research, 4 (4):244249

Nieuwentus, R., Nieuwelink, J. 2002. Agrodok Series No. 10 CTA: The Netherlands pp 28- 30.

Olusola Ladokun, Sarah Oni. 2014. Fermented Milk Products from Different Milk Types, Scientific Research Publishing Inc, 12281233

Persley, J.G.1992. Replanting of the Tree of Life, CAB International Wallingford Oxon $38-40$.

Potter, R.M., et al.2007. Characteristics of wild blueberry-soy beverages. Food Science and Technology, 40 (5). 807-814.

Ranganadham, M., Gupta, S.K. 1987. Indian Dairyman. 39 (10): 493 
Reed, G. 1982. Prescot and Dunn's Industrial Microbiology, $4^{\text {th }}$ Edition. Macmillan Publishers, London, 146-173

Singh, G., Muthukun, K. 2008. Food Sci Technol, 41, 1145-1152.

Soler, L. 2005. Development of non-dairy frozen emulsion containing soy protein and coconut milk. Louisiana State University and Agricultural and Mechanical College, Louisiana

Stone H, Sidel JL (1993) Sensory Evaluation Practices. San Diego, CA: Academic Press

Tarrega A., Costell, E. 2007. Color and consistency of semi-solid dairy desserts: Instrumental and sensory measurements. Journal of Food Engineering 78(2). 655661.

Thai Food Composition .2004. Institute of Nutrition Mahidol University. Thailand. 150.

Tull, A. 1996. Food and Nutrition. Oxford University Press, 109-111. 